\title{
Accounting
}

\section{Cloud accounting information systems: Threats and advantages}

\author{
Esra Al-Nsour ${ }^{a^{*}}$, Sulaiman Weshah ${ }^{\mathrm{a}}$ and Ahmad Dahiyat ${ }^{\mathrm{a}}$
}

\begin{tabular}{l}
${ }^{a}$ Al-Balqa Applied University, Jordan \\
\hline C H R O N I C L E \\
\hline Article history: \\
Received: November 28, 2020 \\
Received in revised format: \\
December 282020 \\
Accepted: January 26, 2021 \\
Available online: \\
January 26, 2021 \\
\hline Keywords: \\
Cloud Accounting Information \\
System \\
External Auditors \\
Advantages \\
Threats \\
Jordan
\end{tabular}

\begin{abstract}
A B S T R A C T
When the Corona-virus pandemic hit the world, executing and performing the jobs of the remote world became an imperative, this pandemic became as motivator to create this study which aimed to reveal the advantages and threats that encounter the implementing of Cloud Accounting Information Systems CAIS from the view point of external auditors. For that purpose, a questionnaire was developed and distributed then from 198 valid questionnaires which were analyzed by a T- test. It has been found that the main advantages are a reduction of labor and overtime costs because of the ability to access the system from anywhere, while penetration, interruption, and confidentiality are the main threats, also it was found that there is a strong relationship between implementing cloud accounting information systems (CAIS) and the limiting manipulation of financial information. The study therefore recommended upgrading the security procedures of cloud accounting systems and holding courses for auditors to enhance their abilities in auditing CAIS.
\end{abstract}

(C) 2021 by the authors; licensee Growing Science, Canada

\section{Introduction}

Technology is an integral part of living in the 20th century (Cloete, 2017). That is the company's modern technical accounting system plays a great role in assisting managers to execute key management functions and making decisions, and remote work became a must as a result of the Corona pandemic. cloud accounting information systems (CAIS) reduces attempts to penetrate and manipulate data and engage in fraud. Tremendous developments in the use of the internet in different areas have resulted in the emergence of cloud accounting. This study is vital for external auditors because it examines the risks that may arise when using CAISs, so they will assess the efficiency of internal controls in companies, and type of skills they need to improve in order to meet the requirements of their jobs, the changes in auditing was affected by business globalization, modern technologies acceleration and demand on audit added value. For companies, this study illustrates the advantages and risks of using cloud accounting systems, which will help them to make the appropriate decisions regarding the adequacy of internal controls, the strengths of these controls and how to enhance them, as well as the risks of such systems and how to minimize them. Moreover, the study will enable accounting students to know about trends in the labor market and available employment opportunities, so that they can improve their skills to meet the requirements of the labor market. It is necessary nowadays in all sizes of organizations to use electronic data processing for more effectiveness and efficiency (Romney \& Steinbart, 2018). Currently within Coronavirus pandemic the role of executing needed tasks remotely increased and online websites and applications played

* Corresponding author

E-mail address: Esra.alnsour@bau.edu.jo (E. Al-Nsour) 
a big role (Mukhopadhyay \& Mukhopadhyay, 2020), which may indicate how the depending on CAIS will be increased and that lightening the importance of current study. Constrained by the real worldwide economic context, organizations are effectively engaged in finding new productive methods to enhance the effectiveness and profitability of their businesses (Christauskas \& Miseviciene, 2012). The continuous challenges across the world force all entities in the financial field to be competitive, dynamic, and active. Financial information created by accounting information systems fulfills different needs: business valuations, decision making processes, planning and controlling, for example. Cloud accounting is the newest accounting pattern. It uses software hosted on a remote server. In cloud accounting, information is transferred to a cloud, where it is additionally processed, and then the user retrieves it. This means that it is not necessary to execute different accounting functions inside the company, but accountants can perform their job from any place where access to the internet is available. The continuing changes in cloud accounting influence a wide variety of ventures and enterprises, and all entrepreneurs will at some point or another face the effect of these changes. Cloud accounting is the correct decision for any business wishing to keep pace with its competitors. Cloud accounting can be extremely profitable for SMEs, as it allows accounting functions to be executed at a lower cost. The customization offered by cloud accounting is an extraordinary advantage to any business, and empowers the business, whether it is small, medium or large, to customize the cloud software as required by its own circumstances. Cloud accounting has gotten high consideration for its minimal effort, high-effectiveness method of accounting information system based on the internet and users have to pay only the amount that enable them to access to the internet, with the expansion of benefits obtained from the usage of CAIS multinational corporations will implement this model to obtain the benefits from that (Zhang, 2014).

Christauskas and Martinkus (2004) illustrated the primary goal of an accounting system is to represent, by the accumulation and recording of information and data that have economic effect, the financial position of the business and to communicate this information to internal and external parties. E-accounting helps the management to carry out all its functions effectively, easily, accurately, and more flexibly than before, through using the internet (Güney, 2014). In other words, cloud accounting has become a new business model that helps a company to execute its accounting functions professionally (Dimitriu \& Mateia, 2015). Costs and efficiency have been given as the explanations behind the utilization of cloud accounting, while the absence of awareness of the advantages of using cloud accounting, and poor security, have been described as the most vital drivers for misuse. It has also been highlighted that the acceptance of CAIS among SMEs is relatively low (Sahandi et al, 2013). Abu-Musa (2005) found that $50 \%$ of Saudi organizations experienced huge losses from the internal and external threats that are encountered with computerized accounting information systems, such as the intentional entry of bad data and employees sharing passwords. Loch and Warkentin (1992) revealed in their study that the major threats encountered with CAIS come from inside the organization, while Davis (1996) found that differences between organizations' environments will lead to different levels of risks encountered within the use of CAIS. CAIS can contribute many advantages to users of different types, both internal and external. A cloud system can provide these users with information that can help them in the decision-making process, the availability of information for related parties will enhance the decision-making process and maximize the profitability of the supply chain; compliance with disclosure requirements leads to increased transparency, so the company will provide better goods and services (Siahaan, 2013). CAIS brings the advantage of providing customers with different services, combined with a high level of flexibility and support, which minimizes the cost of utilizing it. With a traditional system, the company is responsible for providing the basic requirements such as hardware and software required to operate the accounting system, while with CAIS all the processing requirements are handled on the servers at the cloud office. With the new type of information technology that relies on the internet, accountants can perform their job from anywhere if they can access the internet. From another perspective, CAIS has a preferential advantage represented by its ease of access and simplicity. CAIS reduces the time needed for executing accounting functions, and also reduces the errors that may occur. CAIS is a new method of executing different accounting functions, storing the related information and retrieving them efficiently (Prichici \& Ionescu, 2015). CAIS minimizes the cost of executing different accounting functions because it is not required to spend money on the acquisition of special applications for accounting (Al-zoubi, 2017). Current study was developed to examine different aspects that have already been examined in previous studies, and also a new aspect, related to the cost of the labor.

\section{Questions posed by the study}

Depending on the wide use of information systems which has become an essential part of conducting business for many small, medium, and large companies (Haynes \& Li, 2016), a future type such as CAIS started to be used by accountants inside organizations. Therefore, some question related to advantages and disadvantages of using such accounting information system type came to the surface, such as the following:

1. Could CAIS be manipulated for personal gain?

2. Do external auditors have the necessary skills that enable them to understand and audit the CAIS?

3 . Would the implementation of CAIS reduce the cost of the labor?

4. Would the adoption of CAIS increase the risks of automated processes? This question has the following sub-questions: 
4.1 Would the implementation of CAIS increase the risk of unauthorized access?

4.2 Would the implementation of CAIS increase the risk of viruses?

4.3 Would the implementation of CAIS increase the risk of breaches of privacy and confidentiality?

\section{Study Model and Study Hypotheses}

This study has a main hypotheses and sub hypotheses:

The main hypothesis is "The use of CAIS leads to reducing risks and achieving benefits from the viewpoint of external auditors".

The following are sub-hypotheses depended on the main hypothesis:

- First sub-hypothesis Ho1: "The use of CAIS does not reduce the manipulation of financial reports".

- Second sub-hypothesis Ho2: "The use of CAIS does not enhance the auditor's ability to access the information necessary to carry out the audit task".

- The third sub-hypothesis Ho3: "The adoption of CAIS does not reduce the cost of manpower".

- $\quad$ Fourth sub-hypothesis Ho4: "The implementation of CAIS does not lead to reducing the risks resulting from its use".

Within Fig. 1 variables of the study are illustrated where the use of CAIS represents an independent variable and manipulation of financial reports, enhance the auditor's ability to access the information necessary to carry out the audit task, reduction of labor cost and the risks associated with the implementation of CAIS.

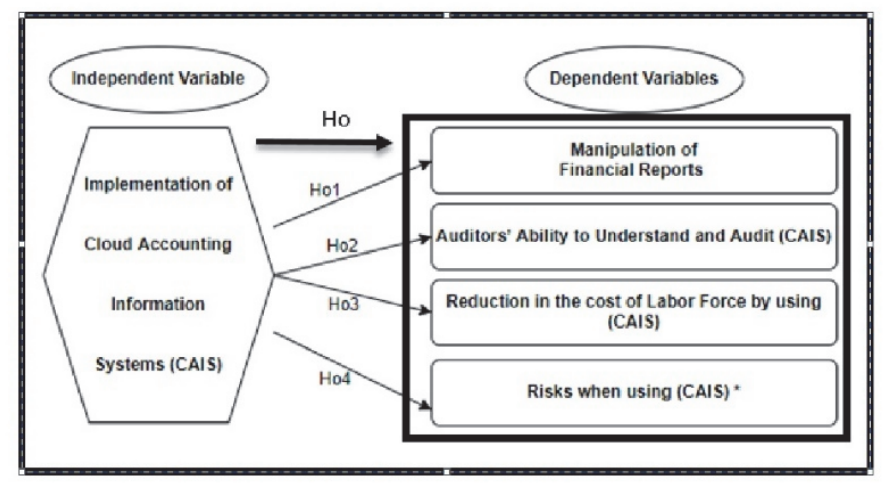

Fig. 1. The study model and hypothesis

* Risks here determined from Unauthorized Access, Viruses, and Privacy and Confidentiality risks.

\section{Study methodology}

A questionnaire was developed and distributed on the population of the study that is the Jordanian Audit Offices. The study population consisted of external certified accountants who are members in the Association of Chartered Accountants. (JCPA), and their number until the end of 2019 was (384) practicing legal auditors, a questionnaire was distributed over the study sample, and the number of retrieved questionnaires reached (221), of which (198) were valid for statistical analysis, after excluding (23) questionnaires for their unsuitability for statistical analysis, so the percentage of recovered and analyzable questionnaires was $(82.5 \%)$.

The study relied on collecting data on two types of sources:

- Secondary sources included the literature that dealt with the subject of the study, and

- Primary sources included a questionnaire that was designed in a way that suits the subject.

The study data was analyzed through the use of (Statistical Package for Social Sciences - SPSS), Descriptive Statistics deviations, Internal consistency coefficient (Cronbach Alpha), to measure the stability of the study instrument and One-Sample t-test to test the study hypotheses. 


\section{Testing the stability of the variables}

The Cronbach Alpha internal consistency coefficient was measured for the study variables and their directions and for the study tool as a whole, to see the extent of consistency in the answers. This is as follows:

Table 1

The values of the coefficients of internal consistency for the paragraphs

\begin{tabular}{|c|c|c|c|c|}
\hline No. & Study variables & Paragraphs & No. of paragraphs & Alpha Value \\
\hline 1 & Role of the CAIS in reducing the manipulation of financial reports & $1-6$ & 6 & 0.779 \\
\hline 2 & $\begin{array}{l}\text { Role of the CAIS in enhancing the auditor's ability to access necessary information to } \\
\text { understand and audit CAIS }\end{array}$ & $7-12$ & 6 & 0.740 \\
\hline 3 & Role of the CAIS in reducing the cost of the workforce & $13-18$ & 6 & 0.648 \\
\hline 4 & Risks arising from using the CAIS information system & $19-25$ & 7 & 0.801 \\
\hline \multicolumn{3}{|c|}{ All paragraphs } & 25 & 0.884 \\
\hline
\end{tabular}

Table 1 indicates that the values of the Cronbach alpha coefficient of internal consistency for the paragraphs of the study tool ranged from (0.648-0.801), and the value of the Cronbach alpha coefficient for all paragraphs of the study tool was (0.884), and therefore all values are greater than (0.60) and this is an indication of consistency Among the items of the study tool, the reliability of the study tool and its reliability for performing statistical analysis.

\section{Respondents' answers description and hypotheses testing}

The arithmetic averages (aa), standard deviations (sd), and ranks(r) of relative importance (ri) were relied upon in describing the responses of the sample members to the paragraphs of the questionnaire, and the results were as follows:

\section{Table 2}

Description of the responses of the sample members on the paragraphs of the questionnaire

\begin{tabular}{|c|c|c|c|c|}
\hline Study Variables & aa & sd & $\mathbf{r}$ & ri \\
\hline Role of the CAIS in reducing the manipulation the financial reporting & 3.965 & 0.571 & 2 & Elevated \\
\hline Role of CAIS to enhance auditor's ability to understand and audit CAIS & 3.950 & 0.524 & 3 & elevated \\
\hline Role of CAIS in reducing labor force cost & 4.022 & 0.454 & 1 & high \\
\hline Risks resulting from use of CAIS & 3.882 & 0.513 & 4 & high \\
\hline Threats and advantages of using CAIS & 3.955 & 0.402 & 1 & High \\
\hline
\end{tabular}

It is evident from Table 2 that the general measure of the sample's attitudes about the threats and advantages of applying CAIS from the viewpoint of Jordanian external auditors in terms of relative importance was high, as the mean was (3.955), and with a standard deviation (0.402). All dimensions appeared with a high relative importance, as it came after (the role of the CAIS in reducing the cost of manpower) in the first place, with an arithmetic average (4.022), a standard deviation (0.454), and a high relative importance, while it came after (the resulting risks from the use of the CAIS) in the last place, with an arithmetic mean (3.882), a standard deviation (0.513), and with high relative importance.

\subsection{The main sub-hypothesis}

The main hypotheses of the study and sub hypotheses were subjected to a (t) test for one sample, as this test was relied upon to verify the extent to which the answers of the study sample differ from the value (3.0), which represents the average selection of the responses of the sample members from the items of the study tool. Judging the significance of the value (t) of the difference between the arithmetic mean of the responses of the sample members on the axis with the (default) reference arithmetic mean through the value of (Sig t), where the difference is statistically significant if the value of (Sig t) is less than 0.05 . The results are as follows:

The main hypothesis states that: "The easing of the CAIS does not lead to reducing risks and achieving benefits from the viewpoint of external Jordanian auditors". Table 3 shows the results:

Table 3

The results of the main hypothesis

\begin{tabular}{lcccccc}
\hline Hypothesis & Arithmetic mean & $\begin{array}{c}\text { Standard } \\
\text { deviation }\end{array}$ & $\begin{array}{c}\text { Default } \\
\text { arithmetic mean }\end{array}$ & $\begin{array}{c}\text { Difference } \\
\text { between the two }\end{array}$ & $\begin{array}{c}\text { Calculated t } \\
\text { Significance level } \\
\text { Sig t }\end{array}$ & $\begin{array}{c}\text { * } \\
\text { Ho }\end{array}$ \\
\hline
\end{tabular}

Table 3 indicates that the arithmetic mean of the role of applying a CAIS in reducing risks and achieving benefits from the 
viewpoint of external auditors reached (3.9747), which is greater than the approved standard or reference arithmetic mean of (3.0), with a difference of (0.9747) and this difference is considered significant, which indicates that there is a role for the CAIS in reducing risks and achieving benefits from the viewpoint of sample members, and this means rejecting The main hypothesis and accepting of the alternative one which states: "The using of the CAIS leads to reducing risks and achieving benefits from the viewpoint of Jordanian external auditors"

\subsubsection{The Second sub-hypothesis}

The first sub- hypothesis states: "The implementing of the CAIS does not reduce the manipulation of financial reports.". Table 4 shows the results of the one sample t-test, which is related to the first sub- hypothesis.

Table 4

The results of the first hypothesis

\begin{tabular}{lccccc}
\hline Hypothesis & Arithmetic mean & $\begin{array}{c}\text { Standard } \\
\text { deviation }\end{array}$ & $\begin{array}{c}\text { Default } \\
\text { arithmetic mean }\end{array}$ & $\begin{array}{c}\text { Difference } \\
\text { between the two }\end{array}$ & $\begin{array}{c}\text { Calculated t } \\
\text { Significance level } \\
\text { Sig } \mathbf{~}\end{array}$ \\
\hline Hol & 3.9899 & 0.5960 & 3.000 & 0.9899 & 23.371 \\
\hline
\end{tabular}

Table 4 indicates that the arithmetic mean of the role of applying a CAIS in reducing manipulation of financial reports from the viewpoint of external auditors has reached (3.9899), which is greater than the approved standard or reference arithmetic mean of (3.0), with a difference of its amount. (0.9899) this difference is considered significant, which indicates there is a role for the CAIS in limiting the manipulation of financial reports from the viewpoint of the external auditors, and this means rejecting the first sub-hypothesis and accepting the alternative one which state: "The applying of the CAIS leads to the reduction of manipulation of financial reports"

\subsubsection{The Second sub-hypothesis}

The second sub-hypothesis states: “implementing the CAIS does not lead to enhance the auditor's ability to access necessary information to understand and audit CAIS". Table 5 shows the results, related to the second sub-hypothesis.

Table 5

The results of the second hypothesis

\begin{tabular}{lcccccc}
\hline Hypothesis & Arithmetic mean & $\begin{array}{c}\text { Standard } \\
\text { deviation }\end{array}$ & $\begin{array}{c}\text { Default } \\
\text { arithmetic mean }\end{array}$ & $\begin{array}{c}\text { Difference } \\
\text { between the two }\end{array}$ & $\begin{array}{c}\text { Calculated t } \\
\text { Significance level } \\
\text { Sig t }\end{array}$ \\
\hline $\mathrm{Ho} 2$ & 3.9697 & 0.5418 & 3.000 & 0.9697 & 25.187 & 0.000 \\
\hline
\end{tabular}

Table 5 data indicate that the arithmetic mean of the role of applying the CAIS in enhancing the auditor's ability to understand and audit from the viewpoint of external auditors has reached (3.9697), which is greater than the approved standard or reference arithmetic mean of (3.0), with a difference of its amount. (0.9697), this difference is considered significant, which indicates that CAIS has a role in helping auditors obtain necessary information that enables them to understand and audit CAIS from the viewpoint of the external auditors. So that means rejecting the second sub-hypothesis and accepting the alternative which states: "The implementation of the CAIS enhances the auditor's ability to get necessary information that enables them to carry out the audit tasks".

\subsubsection{The third sub-hypothesis}

The third sub-hypothesis states that: "The applying of a CAIS does not reduce the cost of labor force". The following table shows the results of the third sub-hypothesis.

\section{Table 7}

The results of the t-test for the third sub-hypothesis

\begin{tabular}{lcccccc}
\hline Hypothesis & Arithmetic mean & $\begin{array}{c}\text { Standard } \\
\text { deviation }\end{array}$ & $\begin{array}{c}\text { Default } \\
\text { arithmetic mean }\end{array}$ & $\begin{array}{c}\text { Difference } \\
\text { between the two }\end{array}$ & $\begin{array}{c}\text { Calculated t } \\
\text { Significance level } \\
\text { Sig t }\end{array}$ \\
\hline Ho3 & 4.0303 & 0.4607 & 3.000 & 1.0303 & 31.466 & 0.000 \\
\hline
\end{tabular}

Table 6 indicates that the arithmetic mean of the role of applying the CAIS in reducing the cost of the workforce from the viewpoint of external auditors has reached (4.0303), which is greater than the approved standard or reference arithmetic mean of (3.0), with a difference of (1.0303). This difference is considered significant, which indicates the role for the CAIS in reducing the cost of workforce from the viewpoint of the external auditors, and this means rejecting the third sub-hypothesis and accepting the alternative, which states: "The role of the CAIS in reducing the cost of the workforce" 


\subsubsection{The fourth sub-hypothesis}

The fourth sub-hypothesis states that: "The use of the CAIS does not lead to reducing the risks resulting from its use". The following table shows the results related to the fourth sub-hypothesis.

Table 7

The results of the t-test for the fourth sub-hypothesis

\begin{tabular}{lcccccc}
\hline Hypothesis & Arithmetic mean & $\begin{array}{c}\text { Standard } \\
\text { deviation }\end{array}$ & $\begin{array}{c}\text { Default } \\
\text { arithmetic mean }\end{array}$ & $\begin{array}{c}\text { Difference } \\
\text { between the two }\end{array}$ & $\begin{array}{c}\text { Calculated t } \\
\text { Significance level } \\
\text { Sig } \mathbf{t} *\end{array}$ \\
\hline Ho4 & 3.8586 & 0.5702 & 3.000 & 0.8586 & 21.190 & 0.000 \\
\hline
\end{tabular}

Table 7 indicates that the arithmetic mean of the role of applying a CAIS in reducing risks arising from its use from the viewpoint of external auditors has reached (3.8586), which is greater than the approved standard or reference arithmetic mean (3.0), with a difference of its amount. (0.8586) This difference is considered significant which means the existence of a role for the CAIS in reducing the risks resulting from its use from the viewpoint of the external auditors, and this Means rejecting the fourth subhypothesis and accepting the alternative which states: "The using of the CAIS reduces the risks arising from its use".

\section{Conclusions and recommendations}

Using a CAIS will reduce the cost of labor and overtime because of the ability to access the system from anywhere that allows employees to finish their jobs without the need to be inside the organization's building, which means that overtime costs, plus other costs that may be incurred from the presence of employees inside the organization's building, are minimized. (Ionescu et.al, 2013) found the same results according that companies can minimize their costs when using CAIS. This agreement with Felsberger et al. (2017) which declared that human skills with the capabilities of computers to provide efficient management of data, reporting, analytics, modeling and planning issues are reflected in cost reduction. Moreover, there is a strong relationship between using a CAIS and preventing the manipulation of financial reports for personal gain. In addition, CAIS helps auditors in getting the desired information that enables them to execute the auditing task. This, going parallel with the result of (AlBashtawi \& Al-Husban, 2013) where they emphasized the need of enhancing auditing skills for auditors within the electronic accounting information systems environment. CAIS may face threats, especially from unauthorized access and breaches of privacy and confidentiality. There are various disadvantages of using CAIS, related to the interruption of the internet connection between the customer and the server, they cannot use it while they lack an internet connection. Also, performing tasks may be delayed as a result of a company's short bandwidth where some components may be lost when upgrading a system. Cloud accounting boasts the advantage of low investment cost, low maintenance costs, low barriers to entry, while the continuous development of cloud accounting, as revealed by (Zhang, 2014). The cost of IT department employee's salaries also will be reduced by using CAISs. Those results motivate to a group of recommendations revealed as per the following:

- Companies must strengthen the implemented internal controls to provide a better protection for a CAIS against different security threats.

- Auditors have to enhance their abilities in order to audit CAISs, and must suggest control procedures that prevent the perceived threats.

- Training courses needed to be held for employees regarding safety and security controls in CAIS, and employees should be encouraged to be committed and dedicated to these procedures.

- More research is needed to obtain evidence from other developing countries.

As Oldhouser (2016) declared that blocks Chain and Extensible Business Reporting Language - XBRL, which are related to accounting information systems needed to be taken into account for future practical fields for accountants and auditors. In addition, for future research within the current Coronavirus pandemic, the field needs more papers discussing clouded services in general and CAISs specifically.

\section{Acknowledgement}

The authors wish to thank auditing firms in Jordan that allowed to distribute questionnaire on external auditors and make it easier to complete the current study.

\section{References}

Abu-Musa, A. A. (2006). Investigating the perceived threats of computerized accounting information systems in developing countries: An empirical study on Saudi organizations. Journal of King Saud University - Computer and Information Sciences, $18,1-30$. 
Al-Bashtawi, S., \& Al-Husban, A. (2013). Determinants of auditing electronic accounting information systems: A case study in the Jordanian commercial banks. European Scientific Journal, 9(10), 118-136.

Al-Zoubi, A. M. (2017). The effect of cloud computing on elements of accounting information system. Global Journal of Management and Business, 17(3-D).

Christauskas, C., \& Miseviciene, R. (2012). Cloud computing-based accounting for small to medium sized business. Inzinerine Ekonomika - Engineering Economics, 23(1), 14-21.

Christauskas, C. \& Martinkus, B. (2004). Information system for accounting. Folia Oeconomica: Accounting Change in the Period of Economic Transformation in Poland and Lithuania, 173,15-22.

Cloete, A.L. (2017). Technology and education: Challenges and opportunities. HTS Teologiese Studies/ Theological Studies 73(4), a4589. https://doi.org/ 10.4102/hts. v73i4.4589

Davis, C. E. (1996). Perceived security threats to today's accounting information systems: A survey of CISA's. IS Audit \& Control Journal, 3, 38-41.

Dimitriu, O., \& Matei, M. (2015). Cloud accounting: A new business model in a challenging context. Procedia Economics and Finance, 32, 665-671. 10.1016/S2212-5671(15)01447-1.

Felsberger, A., Oberegger, B., \& Reiner, G. (2017). A review of decision support systems for manufacturing systems. $i-K N O W$ 2016, Andreas Felsberger on 16 February 2017.

Güney, A. (2014). Role of technology in accounting and e-accounting. Procedia - Social and Behavioral Sciences, 152, 852855.

Haynes, R., \& Li, C. (2016). Continuous audit and enterprise resource planning systems: A case study of ERP rollouts in the Houston, TX oil and gas industries. Journal of Emerging Technologies in Accounting, 13(1), 171-179.

Loch, K. D, Carr, H. H, \& Warkentin, M. (1992). Threats to information systems: Today’s reality, yesterday's understanding. MIS - Computer Security, 15(2), 173-186.

Ionescu, B., Ionescu, I., Bendovschi, A., \& Tudoran, L. (2013, June). Traditional accounting vs. Cloud accounting. In Proceedings of the 8th International Conference Accounting and Management Information Systems, AMIS (pp. 106-125).

Mukhopadhyay, B., \& Mukhopadhyay, B.K. (2020). Effectively Managing Remote Workplace during COVID-19. The Sentinel, Post-Editorial, 19th March

Oldhouser, M. C. (2016). The Effects of Emerging Technologies on Data in Auditing, Master thesis in University of South Carolina - Columbia.

Prichici, C., \& Ionescu, B. (2015). Cloud accounting-A new paradigm of accounting policies. SEA-Practical Application of Science, 1(7), 489-496.

Romney, M. B., Steinbart, P. J., \& Cushing, B. E. (2000). Accounting information systems (Vol. 2). Upper Saddle River, NJ: Prentice Hall.

Siahaan, F. O. (2013). Standardization online accounting system based on information technology. International Journal of Business and Social Science, 4(12).

Zhang, C. (2014). Challenges and strategies of promoting cloud accounting. Management \& Engineering Journal, 17, 18385745 .

www.researchgate.net

www.wikipedia.org 
(C) 2021 by the authors; licensee Growing Science, Canada. This is an open access article distributed under the terms and conditions of the Creative Commons Attribution (CC-BY) license (http://creativecommons.org/licenses/by/4.0/). 